\title{
Pathogenic Vibrio species isolated from estuarine environments (Ceará, Brazil) - antimicrobial resistance and virulence potential profiles

\author{
FRANCISCA G.R. DE MENEZES ${ }^{1}$, MARINA T.T. RODRIGUEZ ${ }^{2}$, FÁTIMA C.T. \\ DE CARVALHO ${ }^{1}$, ROSA H. REBOUÇAS ${ }^{2}$, RENATA A. COSTA ${ }^{3}$, OSCARINA \\ V. DE SOUSA ${ }^{2}$, ERNESTO HOFER ${ }^{4}$ and REGINE H.S.F. VIEIRA ${ }^{2}$
}

\author{
${ }^{1}$ Universidade Federal do Ceará, Departamento de Engenharia de Pesca, Av. Mister Hull, s/n, \\ Campus Universitário do Pici - UFC, Antônio Bezerra, 60455-460 Fortaleza, CE, Brazil \\ ${ }^{2}$ Universidade Federal do Ceará, Instituto de Ciências do Mar/LABOMAR, Av. da \\ Abolição, 3207, Meireles, 60165-081 Fortaleza, CE, Brazil \\ ${ }^{3}$ Instituto Superior de Teologia Aplicada/INTA, R. Antônio Rodrigues Magalhães, \\ 359, Dom Expedito, 62050-100 Sobral, CE, Brazil \\ ${ }^{4}$ Instituto Oswaldo Cruz/FIOCRUZ, Av. Brasil, 4365, Manguinhos, 21040-360 Rio de Janeiro, RJ, Brazil \\ Manuscript received on April 14, 2016; accepted for publication on October 15, 2016
}

\begin{abstract}
Detection of virulent strains associated with aquatic environment is a current concern for the management and control of human and animal health. Thus, Vibrio diversity was investigated in four estuaries from state of Ceará (Pacoti, Choró, Pirangi and Jaguaribe) followed by antimicrobial susceptibility to different antimicrobials used in aquaculture and detection of main virulence factors to human health. Isolation and identification were performed on TCBS agar (selective medium) and dichotomous key based on biochemical characteristics, respectively. Nineteen strains of genus Vibrio were catalogued. Vibrio parahaemolyticus (Choró River) and V. alginolyticus (Pacoti River) were the most abundant species in the four estuaries. All strains were submitted to disk diffusion technique (15 antimicrobials were tested). Resistance was found to: penicillin $(82 \%)$, ampicillin $(54 \%)$, cephalotin $(7 \%)$, aztreonan $(1 \%)$, gentamicin, cefotaxime and ceftriaxone $(0.5 \%)$. Five pathogenic strains were chosen to verification of virulence factors. Four estuaries showed a high abundance of species. High number of tested positive strains for virulence is concerning, since some of those strains are associated to human diseases, while others are known pathogens of aquatic organisms.
\end{abstract}

Key word: Vibrio spp., pathogen, estuaries, public health, water.

\section{INTRODUCTION}

The mangrove ecosystem is widely studied because of its connection to a number of functions and services, such as nutrient cycling (Cannicci et al. 2009), high productivity industries, protection

Correspondence to: Francisca Gleire Rodrigues de Menezes

E-mail: gleirerodrigues@yahoo.com.br against erosion and floods on coastal environments (Field 1995) and maintenance of various species of flora and fauna (Marins et al. 2007).

Following the development of aquaculture, the therapeutic use of antimicrobial agents has increased to the point that their residues have been often detected in the environment (Mudryk 2005). 
These compounds are used as drugs in human and veterinary medicine for the prevention and treatment of diseases (Kim et al. 2007). After the initial use of such substances, some pathogenic bacteria began to show signs of resistance (Grohmann et al. 2003), which can be transmitted through plasmids, transposons, gene cassettes or other mobile genetic elements, making it possible for horizontal transfer to occur between the lineage, species and various genera through existing genetic mobility (Yates et al. 2004).

A group of microorganisms known for acting as a reservoir and vehicle of resistance is the Vibrio genus. They respond to the selective pressure of the environment and are able to spread this character through horizontal exchange of genetic material (Dang et al. 2008).

Many researchers have already conducted studies in order to evaluate the antimicrobial susceptibility of the species in this genus (Costa et al. 2008a, Rebouças et al. 2011). The most studied are Vibrio parahaemolyticus, V. vulnificus (Han et al. 2007), V. alginolyticus (Krishna et al. 2006) and V. cholerae (Okuda et al. 2006).

This research aimed to study the diversity of the Vibrio genus in four estuaries in the state of Ceará (Pacoti, Choró, Pirangi and Jaguaribe), determine their antimicrobial susceptibility to different antibiotics usually employed in aquaculture and research virulence factors relevant to human health.

\section{MATERIALS AND METHODS}

\section{SAMPLING SITE}

Sampling was conducted in the estuaries of Pacoti, Choró, Pirangi and Jaguaribe rivers, in the east coast of Ceará, Brazil, between January and April of 2009. A total number of 64 samples were gathered, 32 of water and 32 of sediment. In each estuary two points were selected, one closer to the sea; the other, farther away. Sampling points for water and sediment and their respective coordinates were registered by a Garmin III Plus GPS device: Pacoti 1 - 03'49'16.6" S and 038 $24^{\circ}$ ' 11.7" W, Pacoti $2-03^{\circ} 48^{\prime} 52.4^{\prime \prime} \mathrm{S}$ and $038^{\circ} 24^{\prime} 38.1^{\prime} \mathrm{W}$, Choró 1- 04 06'07.2" $\mathrm{S}$ and 038 09' 01.8" W, Choró $2-04^{\circ} 06^{\prime} 13.2^{\prime \prime} \mathrm{S}$ and $038^{\circ} 09^{\prime} 13.8^{\prime \prime} \mathrm{W}$, Pirangi 1- $04^{\circ} 23^{\prime} 11.6$ 'S and $037^{\circ} 50^{\prime} 18.4^{\prime \prime} \mathrm{W}$, Pirangi $2-04^{\circ} 24^{\prime} 03.8^{\prime \prime} \mathrm{S}$ and $037^{\circ} 51^{\prime} 00.3{ }^{\prime \prime} \mathrm{W}$, Jaguaribe 1- $04^{\circ} 25^{\prime} 28.7^{\prime \prime} \mathrm{S}$ and $037^{\circ} 46^{\prime} 22.5^{\prime \prime} \mathrm{W}$, and Jaguaribe $2-04^{\circ} 27^{\prime} 39.9^{\prime \prime} \mathrm{S}$ and $037^{\circ} 47^{\prime} 39.5^{\prime \prime}$ W (Figure 1).

\section{SAMPLING}

The water samples were collected at a depth of $50 \mathrm{~cm}$ with previously sterilized amber-colored bottles of $1000 \mathrm{~mL}$ capacity. The sediment was collected with an appropriated collector. The water and sediment samples were taken in isothermal boxes filled with ice to the Laboratory of Environmental and Fishery Microbiology (LAMAP - UFC) at the Marine Sciences Institute (LABOMAR - UFC), where they were immediately processed.

\section{TEMPERATURE, $\mathrm{pH}$ AND SALINITY MEASUREMENTS}

In each collection were verified physicochemical variables for water samples. The temperature was verified in situ with mercury thermometer (INCOTERM). In the lab, the variables $\mathrm{pH}$ and salinity were determined in potentiometer (MARCONI - PA 200P) and refractometer (ATAGO S/MILL), respectively.

\section{ISOLATION OF Vibrio spp. IN THE ENVIRONMENTAL SAMPLES}

\section{WATER AND SEDIMENT SAMPLES}

The samples were serially diluted, using alkaline peptone water (APW) as a diluent, $\mathrm{pH} 7.5$ to 8.5. For the water samples, $9 \mathrm{~mL}$ of diluent was added to $1 \mathrm{~mL}$ of the sample $\left(10^{-1}\right)$ and later, successive decimal dilutions were prepared, from $10^{-1}$ to $10^{-4}$, 


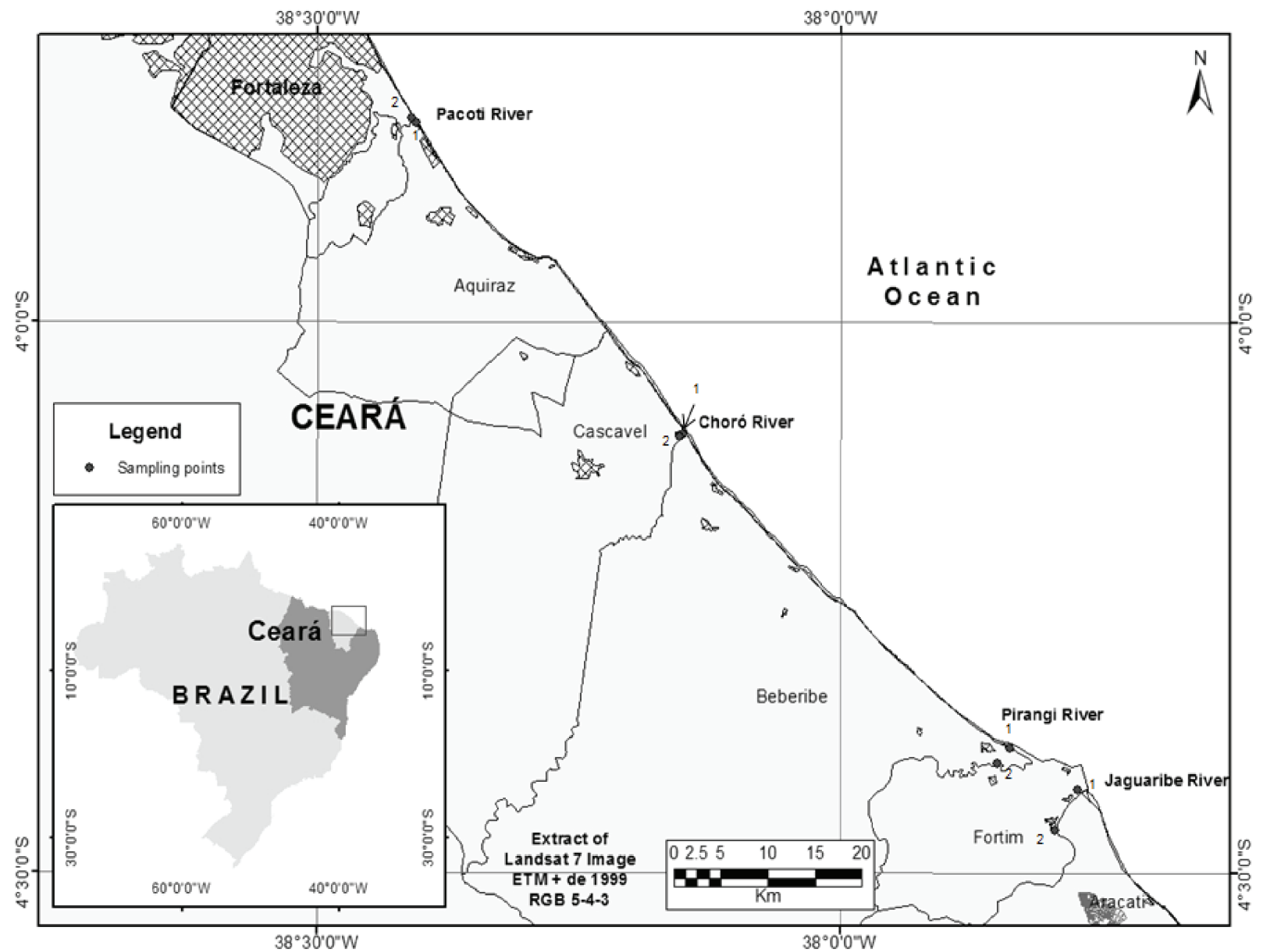

Figure 1 - Map of estuarine collection sites (Pacoti, Choró, Pirangi and Jaguaribe), Ceará, Brazil.

using the same diluent. As for the sediment sample, $25 \mathrm{~g}$ of the sample was weighed and homogenized in $225 \mathrm{~mL}$ of APW for 30 minutes $\left(10^{-1}\right)$. From this initial dilution, serial dilutions were prepared up to $10^{-4}$, using the same diluent.

\section{INITIAL SAMPLE PLATING}

From the previously prepared dilutions, parts of $1 \mathrm{~mL}$ of the sample were inoculated in tubes with APW $+1 \%$ of sodium chloride. Then, parts were taken and streaked on the surface of Thiosulfatecitrate-bile salts-sucrose (TCBS) agar plates. The plates were inverted and left in an incubator, where they remained for 18 hours on $37^{\circ} \mathrm{C}$. Green, blue and yellow colonies were isolated. They bore Vibrio morphological characteristics, opaque and between 2 and $3 \mathrm{~mm}$ of diameter (Kaysner and Depaola 2014).

\section{IDENTIFICATION OF Vibrio spp. ISOLATES AND DETECTION OF POTENTIAL VIRULENCE FACTORS}

\section{CONVENTIONAL MICROBIOLOGICAL TECHNIQUES}

The biochemical identification tests were selected according to the keys reported by Noguerola and Blanch (2008). 
ENZYMATIC AND HAEMOLYTIC PROPERTIES OF THE BACTERIAL CULTURES

Assays gelatinase, caseinase, phospholipase, lipase, elastase and haemolytic activity followed the recommendations proposed in Austin et al. (2005) and Liu et al. (1996). For the detection of potential virulence factors, the strains used as control were Vibrio alginolyticus ATCC 17.749, V. mimicus ATCC 33.653, V. cholerae O1 classic $569 \mathrm{~B}, V$. vulnificus IOC 19.806 and $V$. parahaemolyticus IOC 18.950, obtained from the Oswaldo Cruz Institute - RJ.

\section{ANTIMICROBIAL SUSCEPTIBILITY TEST}

The antibiogram of the isolated and identified Vibrio strains was made through the disc diffusion method (Bauer et al. 1996), following the methodology proposed by Bauer and Kirby.

For the antibiogram, antimicrobial susceptibility discs by LABCLIN (Paraná, Brazil) were used. They belonged to different families: $\beta$-lactam- Aztreonam-ATM $(30 \mu \mathrm{g})$, Ampicillin-AMP $(10 \mu \mathrm{g})$, Penicillin G-PEN (10Ui,), Cephalothin-CFL $(30 \mu \mathrm{g})$, CefotaximeCTX $(30 \mu \mathrm{g})$, Ceftriaxone-CRO $(30 \mu \mathrm{g})$; Aminoglycosides - Gentamicine-GEN $(10 \mu \mathrm{g})$, Streptomycin-STR (10 $\mu$ g); ChloramphenicolChloramphenicol-CLO $(30 \mu \mathrm{g})$, FlorfenicolFLF $(30 \mu \mathrm{g})$; Fluoroquinolones- CiprofloxacinCIP $(5 \mu \mathrm{g})$; Sulfonamides - trimethoprim/ sulfamethoxazole (SXT) $(30 \mu \mathrm{g})$; Quinolones - Nalidixic acid-NAL (30 $\mu$ g) and Tetracycline Tetracycline-TET $(30 \mu \mathrm{g})$, Oxytetracycline-OXI $(30 \mathrm{~g})$, following the orientation of CLSI (2013), exception made to the Oxytetracycline-OXI (30g) (prepared in laboratory). Standard strains used as control were Vibrio parahaemolyticus ATCC 17802 and Vibrio cholerae ATCC 19782.

\section{PLASMID CURING METHOD}

The strains which manifested resistance to more than one antibiotic were subjected to plasmid curing method, according to Molina-Aja et al. (2002) using the LB (Luria-Bertani) broth supplemented with $1 \%$ of $\mathrm{NaCl}$. The agent was the acridine orange dye, in $100 \mu \mathrm{g} / \mathrm{mL}$ concentration.

\section{RESULTS AND DISCUSSION}

The temperature values of the water samples ranged from 28 to $36.5^{\circ} \mathrm{C}$. Temperature and salinity are the factors which affect vibrios distribution the most (Noriega-Orozco et al. 2007).

In addition to temperature, salinity is also a limiting factor in the growth of vibrios. Salinity oscillated between 2.0 and 48.0 in the samples of the four rivers studied. This variation was mainly caused by the location of the sampling points and the volume of rain water received by the rivers during the sampling period. It is worth noting that the samples were taken in the rainy season (January to April) in the state of Ceará, which explains a fluctuation in salinity level enough to interfere with the isolation of microorganisms. Vibrio in general tolerate a wide range of salinity (Eiler et al. 2006). The authors isolated Vibrio species in salinity gradients from 2 to 30.0. Besides temperature and salinity, environmental factors such as phosphor concentration and abundance of dinoflagellates are also important in the prognosis of genus abundance.

The average $\mathrm{pH}$ of the waters varied between 6.96 to 8.32 in the four estuaries studied. These values are within the limits settled for vibrio growth, 7.5 to 8.5 (Sousa 2004). Batabyal et al. (2014) have observed a rise in the Vibrio count with the variation of temperature, $\mathrm{pH}$ and/or salinity.

Some species in water environments belonging to the Vibrio genus are known for their association to food poisoning, as well as environmental contamination, and might cause harm to human beings (Alagappan et al. 2016) 
The number of Vibrio strains were isolated was 212, 98 from the water samples and 114 from the sediment on the estuaries.

In Table I, the diversity of vibrios isolated from the water and sediment in the four estuaries is shown, concluding that the sediments in the Pacoti River (point 1) (where oceanic water exerts more influence) and Choró River (point 2) (located in the most internal part of the estuary) were the places where the isolated species of Vibrio were most diverse.
The four estuaries hold shrimp farming activities, the ones in the proximity of Choró, Pirangi and Jaguaribe rivers are those holding most farms. According to Costa et al. (2010), the farming of marine shrimp in the estuaries is generally associated to nutrient and organic matter discharge in the environment, causing negative impacts in the native microbiota.

The second place in vibrio diversity was Pacoti River, where some of the isolated species are pathogenic to man. Even though Pacoti River

TABLE I

Number of strains of Vibrio species detected in the water and sediment samples collected in the estuaries of rivers Pacoti, Choró, Pirangi and Jaguaribe (Ceará).

\begin{tabular}{|c|c|c|c|c|c|c|c|c|c|}
\hline \multirow{2}{*}{ Vibrio species } & \multicolumn{2}{|c|}{ 1st Sample } & \multicolumn{2}{|c|}{ 2nd Sample } & \multicolumn{2}{|c|}{ 3rd Sample } & \multicolumn{2}{|c|}{ 4th Sample } & \multirow{2}{*}{ Total } \\
\hline & WAT & SED & WAT & SED & WAT & SED & WAT & SED & \\
\hline V. parahaemolyticus & & 1 & & 3 & 17 & 23 & 11 & 12 & 67 \\
\hline V. alginolyticus & 3 & 5 & 8 & 8 & 3 & 3 & 1 & 2 & 33 \\
\hline V. coralliilyticus & 11 & 7 & 6 & & & & 2 & & 26 \\
\hline V. mimicus & 1 & & & & 1 & 1 & 6 & 7 & 16 \\
\hline V. litoralis & 5 & & 1 & 7 & 2 & & & & 15 \\
\hline V. diabolicus & & 5 & & & 2 & 4 & & & 11 \\
\hline $\begin{array}{l}V . \text { cholerae non-O1 } \\
\text { and non-O139 }\end{array}$ & & & & & 3 & 1 & 2 & 3 & 9 \\
\hline$V \cdot$ proteolyticus & & & 1 & 1 & 1 & 1 & & 2 & 6 \\
\hline V. diazotrophicus & 1 & 4 & & & & & & 1 & 6 \\
\hline V. scophthalmi & & 1 & & & 4 & & & & 5 \\
\hline V. vulnificus & & & & 1 & & 1 & 2 & 1 & 5 \\
\hline V. furnissii & & & 1 & 1 & 2 & & & & 4 \\
\hline$V \cdot$ pelagius II & & 1 & & 1 & & & & & 2 \\
\hline$V$. nereis & & 1 & & 1 & & & & & 2 \\
\hline V. ichthyoenteri & & & & 1 & & & & & 1 \\
\hline V. hepatarius & & & & & & & & 1 & 1 \\
\hline V. fischeri & & & & 1 & & & & & 1 \\
\hline V. rumoiensis & 1 & & & & & & & & 1 \\
\hline V. natriegens & & & & & & & & 1 & 1 \\
\hline Total & 22 & 25 & 17 & 25 & 35 & 34 & 24 & 30 & 212 \\
\hline
\end{tabular}


has only one shrimp farm, it is known that the river collects both domestic and industrial sewage and house recreational activities in its waters (Sousa et al. 2006).

Table I shows the number of isolated strains in the environmental samples (water and sediment), in which the most frequent isolates that concern human health are ranked as: Vibrio parahaemolyticus $(\mathrm{n}=67)$, followed by $V$. alginolyticus $(\mathrm{n}=33), V$. coralliilyticus $(\mathrm{n}=26), V$. mimicus $(\mathrm{n}=16), V$. cholerae non-O1 and non-O139 ( $\mathrm{n}=9), V$. vulnificus $(\mathrm{n}=5)$ and $V$. furnissii $(\mathrm{n}=4)$.

The prevailing species in this study were $V$. parahaemolyticus, more abundant in the Choró River, making up a total of 67 strains, isolated from the water and sediment of the four analyzed estuaries. A higher amount of this Vibrio was detected in temperatures that oscillated between 29 and $36.5^{\circ} \mathrm{C}$, with salinity ranging from 2.0 to 35.0. On the fourth sampling, a decrease in salinity occurred, influencing the number of isolated species. On this aspect, Noriega-Orozco et al. (2007) affirm that when there is a rise in temperature, $V$. parahaemolyticus might prevail.

Epidemiological studies have been showing that among the Vibrio species, V. parahaemolyticus is universally distributed and has been isolated from marine food, as well as from estuarine water and sediment, it is also related to gastrointestinal illnesses in man, acquired from raw or undercooked food (Leal et al. 2008, Magalhães et al. 2000).

The second most found species in the samples was $V$. alginolyticus, with a higher incidence in the Pacoti River. This vibrio has been reported as a pathogen to humans, shrimp and sea-food (Noriega-Orozco et al. 2007).

In studies conducted in shrimp farms, $V$. alginolyticus is most of the times involved in bacterial epidemics, being able to cause enteric, systemic or external infections (Mendes et al. 2005). It is important to bear in mind that although $V$. alginolyticus may be responsible for high economic losses in shrimp farming, Vieira et al. (2009) affirm that this species, along $V$. damsela and $V$. fluvialis are indigenous to both environment and shrimp. However, $V$. alginolyticus plays an important epidemiological role as a human pathogen, as it is present in water environments and in the marine animals microbiota, and also quick to infect cuts and exposed skin injuries in marine environment. Rodrigues et al. (2001) researching skin injuries in fishers in the locality of Raposa, Maranhão, detected in order of frequency: $V$. alginolyticus (66\%), V. parahaemolyticus (42\%) and V. cholerae non-O1 (9\%).

The third highest frequency of species is that of $V$. coralliilyticus, 26 identified strains in samples of all estuaries. From these, most were isolated in water samples $(n=19)$. This microorganism is known as a coral pathogen, that might be highly harmful to reefs. In some cases they cause necrosis of the tissues of coral Pocillopora damicornis, when incubated in temperatures between 27 and $29^{\circ} \mathrm{C}$ (Arboleda and Reichardt 2009).

$V$. mimicus, the fourth species in abundance $(n=16)$ was identified in eight water and eight sediment samples. Rebouças et al. (2011) have isolated V.mimicus in samples of the hepatopancreas of the marine shrimp Litopenaeus vannamei, and of pond water in three shrimp farms on the Ceará coast, in the estuaries of the rivers Acaraú, Coreaú and Jaguaribe. $V$. mimicus bears a high degree of similarity to $V$. cholerae (Takahashi et al. 2007). Its main characteristic is being pathogenic to humans, causing gastroenteritis. The clinical symptoms of this disease are associated to a watery diarrhea which is caused by haemolytic enterotoxins produced by the intestines epithelial cells, affecting the ion transport. This suggests that this pathogens, as other species of Vibrio (Mizuno et al. 2009), produce many virulence factors.

Another species with an outstanding epidemiological role is $V$. cholerae, found in the four rivers analyzed. According to Costa et al. 
(2008b), this Vibrio is associated to different stages in the development of marine shrimp, Litopenaeus vannamei. Costa et al. (2010) observed that in the estuary waters of the Acaraú River (Ceará), $V$. cholerae was the second species in abundance. It is concerning, since Thompson et al. (2008) note that this is considered the most dangerous pathogen in the whole world, especially in developing countries. The authors cite that in the year 2006, cholera killed more than 5000 people in Angola, while Haiti also faced a terrifying epidemic in 2011 (Prensa Latina 2011).

Araújo et al. (1996) highlight that, beyond environmental factors, zooplankton, specially copepods, is important in the survival and multiplication of vibrios in aquatic environments. They also mention that $V$. cholerae, in controlled conditions, was able to develop in association to copepods within the limits of salinity $(0,27)$ and $\mathrm{pH}(7,5)$. This claim is reinforced by Vieira et al. (2009), who comments on the ability of $V$. cholerae $\mathrm{O} 1$ to survive in low salinity waters. It concurs with the data found in this study, as the highest abundance of $V$. cholerae non-O1 and non-O139 were made in the last samples, in which the salinity values were the lowest, 2.0 to 7.0.

Vibrio vulnificus, also isolated from water and sediment in this research (Table I), along with $V$. parahaemolyticus and V. cholerae, is considered a pathogen of high risk to public health (Austin 2010, Thompson et al. 2004). Beneduce et al. (2010), analyzing samples of mussel, water and sediment of the Varano Lake, in the Foggia province (Italy), were able to isolate $V$. vulnificus during seven months of study. According to the authors, this vibrio causes food poisoning in humans, but it might cause severe syndromes, deadly in 50 60\% of the cases, therefore considered a high mortality food pathogen. In other respects Mahmud et al. (2007) point that a high $\mathrm{pH}$ allows $V$. vulnificus to go from the cultivable stage to the viable but non- cultivable, resulting in a higher competition of the vibrio against local populations.

V. furnissi, another vibrio isolated in the study, is known for being a free-living bacteria found in marine environments, that has been associated to diseases in eels and shrimp (Srinivasan and Ramasamy 2009, Sung et al. 2001). In Brazil it was famous for its harm to public health; being able to cause light to severe gastroenteritis in children and adults and, in more severe cases, haemolysis of the blood cells (Austin 2010, Magalhães et al. 1993).

The $V$. ichthyoenteri and $V$. fischeri were also isolated in two estuaries, Jaguaribe and Choró, respectively. According to Montes et al. (2006), $V$. fischeri is associated to the regular microbiota of some marine organisms and might cause outbreaks of epizootic, while $V$. ichthyoenteri is the etiologic agent of bacterial enteritis in fish (Sugita and Ito 2006).

The samples with the highest number of Vibrio species were the sediment ones. Kemper (2008) explains that the soil is a reservoir of microorganisms, in which an elevate number of bacteria might be found, from $10^{6}$ to more than $10^{9} \mathrm{UFC} / \mathrm{g}$. In the sediment, $V$. parahaemolyticus prevailed, followed by $V$. alginolyticus (Table I).

Likewise, Duan and Su (2005) worked with samples of oyster, sea water and sediment from Oregon (USA) bays and pointed $V$. parahaemolyticus as the most found species in the sediment. According to the authors the high incidence of $V$. parahaemolyticus in the sediment suggests that it is the largest reservoir of Vibrio in the marine environment. The temperature is one of the biggest influences, as when there a fluctuation in the weather, this microorganism, that lays in the sediment, is able to multiply rapidly and become present in higher levels in the environment (Duan and $\mathrm{Su}$ 2005). This fact, which converges sediment and the vibrio species, is highlighted by Harriague et al. (2008) while analyzing sea water and sediment samples in beaches of the Adriatic Sea (Italy). 
Antibiotics and other chemotherapeutic agents are commonly used in fish and shrimp farms, as additives or immersion baths, depending on the objective, prophylactic or therapeutic (Devi et al. 2009).

In Figure 2, we have the rate of susceptibility/ resistance of the isolated Vibrio strains to different antimicrobials. The highest resistance rate observed was penicillin-PEN (83.2\%), followed by ampicillin-AMP (50.7\%), cephalothin-CFL (5.5\%), aztreonam-ATM (1.5\%), cefotaxime-CTX, ceftriaxone-CRO and gentamicine-GEN $(0.5 \%)$.

Choró River showed the highest number of strains resistant to penicillin (48), followed by the Jaguaribe River (42), Pacoti River (39) and Pirangi
River (35). The Jaguaribe River, on the other hand, showed the highest number of strains resistant to ampicillin (30), followed by the Pirangi (24) and then Pacoti and Choró (23 each). These results agree with Kumar et al. (2009) who, analyzing environmental samples of sea water and sediment, found a high resistance to penicillin and ampicillin. According to the authors, the intrinsic resistance of many marine bacteria is proved, an alarming fact, since this resistance might be transferred to other bacteria by mobile genetic elements, more widely known as plasmids, transposons and integrons. It is worth noting that this character can also be transferred from the marine bacteria to other microorganisms present in the estuaries.

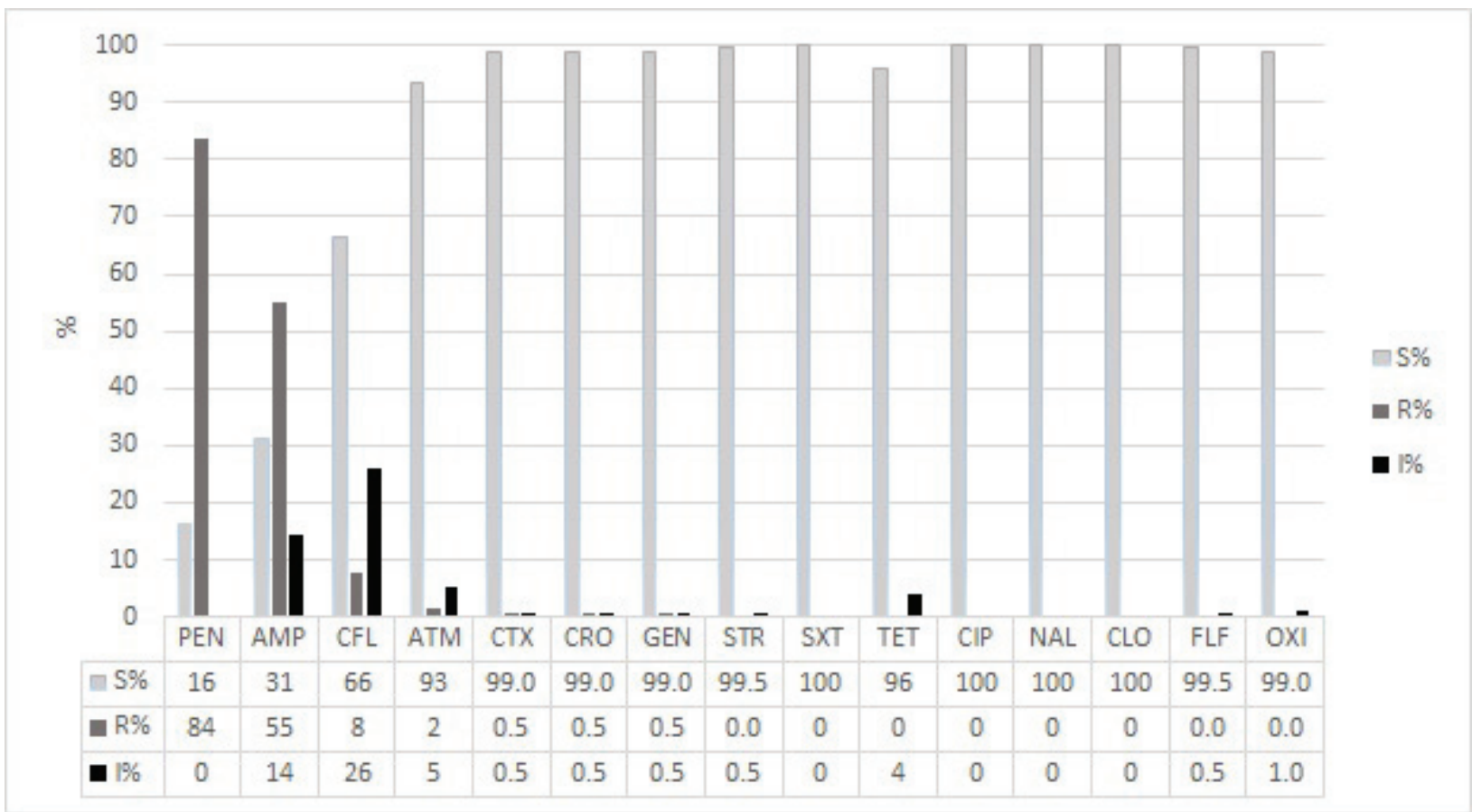

Figure 2 - Percentage of susceptibility to different antimicrobial of 197 strains of Vibrio spp. isolated from water and sediment from the estuaries of Pacoti, Choró, Pirangi and Jaguaribe rivers (Ceará).

PEN - Penicillin; AMP - Ampicillin; CFL - Cephalothin; ATM - Aztreonam; CTX - Cefotaxime; CRO - Ceftriaxone; GEN - Gentamicine; STR - Streptomycin; SXT -trimethoprim/ sulfamethoxazole; TET - Tetracycline; CIP -Ciprofloxacin, NAL- Nalidixic acid; CLO, Chloramphenicol; FLF, Florfenicol; OXI, Oxytetracyclin. S\% $=$ Sensible, R\% $=$ Resistant, $\mathrm{I} \%=$ Intermediary. 
In the same vein, Rebouças et al. (2011) worked with 31 strains of Vibrio, from pond water and marine shrimp from shrimp farms in Ceará. Out of this total, 14 were resistant to ampicillin, followed by oxytetracycline $(n=8)$, cefoxitine $(n=6)$, tetracycline $(n=4)$ and nalidixic acid $(n=2)$. Costa et al. (2008a) also records resistance to ampicillin in vibrios isolated from marine shrimp, Litopenaeus vannamei, and from waters in shrimp farms.

The low incidence of strains resistant to the antimicrobials cephalothin - CFL (5.5\%), aztreonam- ATM (1.5\%), cefotaxime - CTX, ceftriaxone - CRO and gentamicine-GEN $(0.5 \%)$, its detection indicates that somehow the environment is coming into contact with them. This dissemination of the $\mathrm{R}$ gene can become a risk to existing bacterial populations in the long run. Aztreonam- ATM (1.5\%), cefotaxime - CTX and ceftriaxone $-\mathrm{CRO}$ are part of the $\beta$-lactam class. Akinbowale et al. (2006) researching 62 samples of Vibrio isolated from fish, crustaceans and water, found that more than a half $(54.8 \%)$ were resistant to the $\beta$-lactam used, $41.4 \%$ to cephalexin and $23.1 \%$ to cephalothin, values higher than those found in the present study.

Even though the vibrio displayed a low resistance level to gentamicine-GEN $(0.5 \%)$, the use of aminoglycosides, the class of gentamicine and streptomycin, should be avoided, as they present a high degree of toxicity (Araújo et al. 2007). India was one of the countries which banned the use of this substance in cultivation systems (Jayasree et al. 2006).

No strain was resistant to chloramphenicol. This antimicrobial is forbidden in food by the European Community (Mendes et al. 2004) and Brazil (MAPA 2003), due to its serious effects on the farmers (Rahamn et al. 2010).

Of the 197 strains resistant to ampicillin and penicillin, $\mathrm{n}=25$ remained resistant after being subjected to plasmid curing; $n=7$ of $V$. parahaemolyticus, $\mathrm{n}=5$ of $V$. coralliilyticus, $\mathrm{n}=5$ of $V$. litoralis, $\mathrm{n}=5$ of $V$. alginolyticus, $\mathrm{n}=2$ of $V$. proteolyticus and $\mathrm{n}=1$ of $V$. diabolicus.

Devi et al. (2009), while studying the plasmid profile of $V$. parahaemolyticus isolates sampled from a shrimp farm in India, observed that the antimicrobial resistance before and after the curing persisted for ampicillin, polymyxin B, streptomycin, kanamycin, neomycin, chlortetracycline and furazolidone. These results reinforce what Smith (2007) affirms about the plasmid having the ability to carry a variety of resistance genes, including a codified resistance to ampicillin, chloramphenicol, kanamycin, sulfonamide, streptomycin and tetracycline.

Likewise, Hofer et al. (1999, 2001), while working on isolates of $V$. cholerae and Escherichia coli, observed the ability they have to transfer this resistance on to other bacterial families through transference of multiresistant plasmid. Randrianarivelo et al. (2010) recommend that the antimicrobials should be restricted only to therapeutic use and that preventive focus can be more expensive than posterior treatments. Therefore, farmers should use other strategies to control infections. It is worth noting that the contamination of water sources with antimicrobial residues might be responsible for infections which are quite difficult to treat and constitute a risk to public health (Costa et al. 2008c).

Virulence profile of Vibrio strains isolated from estuaries and chosen for being pathogenic to man ( $V$. alginolyticus, $V$. mimicus, $V$. cholerae, $V$. vulnificus and $V$. furnissii) is shown on Table II.

Among the rivers analyzed, the one with the highest number of potentially virulent strains on the water samples was Pacoti river $(n=11)$, followed by Pirangi (9), Choró and Jaguaribe ( $\mathrm{n}=6$ each). As for the sediment samples the order was: Pacoti and Pirangi (9 each), Jaguaribe (7) and Choró (4).

In an analysis of the 212 Vibrio strains isolated from all samples, the highest percentage of positive 
TABLE II

Virulence factor profile shown by potentially pathogenic to man Vibrio spp. in water and sediment samples from the estuaries of Pacoti, Choró, Pirangi and Jaguaribe rivers (Ceará).

\begin{tabular}{|c|c|c|c|c|c|c|c|c|c|c|}
\hline \multirow{2}{*}{$\begin{array}{l}\text { Sampling } \\
\text { location }\end{array}$} & \multirow{2}{*}{$\begin{array}{l}\text { Sample } \\
\text { type }\end{array}$} & \multicolumn{6}{|c|}{ Virulence profile } & \multirow{2}{*}{$\underline{N}$} & \multirow{2}{*}{$\underline{n}$} & \multirow{2}{*}{ Identified species } \\
\hline & & GI & Et & Cs & Ff & Lp & $\mathbf{H m}$ & & & \\
\hline \multirow{7}{*}{ Choró } & \multirow{5}{*}{ Water } & + & - & - & + & - & $\beta$ & 1 & 1 & V. alginolyticus \\
\hline & & + & - & - & + & - & - & 1 & 1 & $V$. alginolyticus \\
\hline & & + & - & - & + & - & - & 1 & 1 & V. mimicus \\
\hline & & + & - & + & + & + & $\beta$ & 1 & 1 & V. alginolyticus \\
\hline & & + & + & + & + & + & $\beta$ & 2 & 2 & $V$. mimicus/V. cholerae \\
\hline & \multirow{2}{*}{ Sediment } & + & - & - & + & - & - & 3 & 1 & V. alginolyticus \\
\hline & & + & - & + & + & + & - & 1 & 1 & V. mimicus \\
\hline \multirow{7}{*}{ Jaguaribe } & \multirow{3}{*}{ Water } & + & - & - & + & + & - & 3 & 2 & $V$. alginolyticus $/ V$. vulnificus \\
\hline & & + & - & - & + & - & - & 1 & 1 & V. mimicus \\
\hline & & + & + & - & + & + & $\beta$ & 2 & 2 & V. mimicus/V. cholerae \\
\hline & \multirow{4}{*}{ Sediment } & - & - & - & + & - & - & 1 & 1 & V. alginolyticus \\
\hline & & + & - & - & + & + & - & 2 & 2 & $V$. alginolyticus $/ V$. vulnificus \\
\hline & & + & + & - & + & - & - & 1 & 2 & V. alginolyticus \\
\hline & & + & - & - & + & - & - & 3 & 3 & $\begin{array}{c}\text { V. mimicus } / V . \text { alginolyticus } / V \\
\text { vulnificus }\end{array}$ \\
\hline \multirow{13}{*}{ Pacoti } & \multirow{9}{*}{ Water } & + & - & - & + & - & - & 2 & 1 & V. alginolyticus \\
\hline & & + & - & - & + & + & $\beta$ & 1 & 1 & V. alginolyticus \\
\hline & & + & - & - & + & - & $\beta$ & 1 & 1 & V. alginolyticus \\
\hline & & + & - & - & + & + & - & 1 & 1 & V. alginolyticus \\
\hline & & + & + & + & + & + & $\beta$ & 1 & 1 & V. mimicus \\
\hline & & + & - & - & + & + & - & 2 & 1 & V. mimicus \\
\hline & & + & + & - & + & + & $\beta$ & 1 & 1 & V. cholerae \\
\hline & & + & - & - & + & + & $\beta$ & 1 & 1 & V. cholerae \\
\hline & & + & - & + & + & - & $\beta$ & 1 & 1 & V. furnisii \\
\hline & \multirow{4}{*}{ Sediment } & + & - & - & + & - & $\beta$ & 1 & 1 & V. alginolyticus \\
\hline & & + & - & - & + & - & - & 3 & 1 & V. alginolyticus \\
\hline & & + & - & - & + & + & - & 3 & 3 & $\begin{array}{c}\text { V. alginolyticus } / V \text {. mimicus } / V \\
\text { cholerae }\end{array}$ \\
\hline & & + & - & - & + & - & - & 2 & 1 & V. mimicus \\
\hline
\end{tabular}


TABLE II (continuation)

\begin{tabular}{|c|c|c|c|c|c|c|c|c|c|c|}
\hline \multirow{2}{*}{$\begin{array}{c}\text { Sampling } \\
\text { location }\end{array}$} & \multirow{2}{*}{$\begin{array}{c}\text { Sample } \\
\text { type }\end{array}$} & \multicolumn{6}{|c|}{ Virulence profile } & \multirow{2}{*}{$\underline{N}$} & \multirow{2}{*}{$\underline{n}$} & \multirow{2}{*}{ Identified species } \\
\hline & & Gl & Et & Cs & Ff & Lp & $\mathrm{Hm}$ & & & \\
\hline \multirow{11}{*}{ Pirangi } & \multirow{5}{*}{ Water } & - & - & - & - & - & - & 1 & 1 & V. furnisii \\
\hline & & + & - & - & + & - & $\beta$ & 2 & 1 & V. alginolyticus \\
\hline & & + & - & - & + & - & - & 3 & 2 & $V$. alginolyticus $/ V$. cholerae \\
\hline & & + & - & - & + & + & - & 1 & 1 & V. alginolyticus \\
\hline & & + & - & + & + & + & $\beta$ & 2 & 2 & V. mimicus/V. vulnificus \\
\hline & \multirow{6}{*}{ Sediment } & + & - & - & + & - & - & 2 & 1 & V. alginolyticus \\
\hline & & + & - & - & + & + & $\beta$ & 1 & 1 & V. alginolyticus \\
\hline & & + & + & - & + & + & $\beta$ & 2 & 2 & V. alginolyticus/V. cholerae \\
\hline & & + & - & + & + & + & $\beta$ & 1 & 1 & V. mimicus \\
\hline & & + & + & + & + & + & $\beta$ & 2 & 2 & V. mimicus/V. cholerae \\
\hline & & + & - & - & + & - & $\beta$ & 1 & 1 & V. cholerae \\
\hline
\end{tabular}

Gl: Gelatinase; Et: Elastase; Cs: Caseinase; Ff: Phopholipase; Lp: Lipase; Hm: Haemolysis; $\beta=$ beta haemolysis; $\underline{N}$ : number of isolated showing the profile; $\underline{n}$ : number of species.

tests was for phospholipase (98\%), followed by gelatinase $(96 \%)$, lipase $(49 \%), \beta$-haemolytic activity (39\%) and caseinase and elastase $(18 \%)$ (Table II). The results are close to those in Masini et al. (2007). The authors observed that the vibrios originating from the water samples in a bath resort in Italy showed a high percentage of positivity for gelatinase ( $86 \%)$, followed by elastase (73\%), lipase (54\%), protease (14\%), urease (7\%) and haemolytic activity (3\%). They also verified that the production of gelatinase and protease were related to the $V$. alginolyticus and $V$. parahaemolyticus species. In this research, the activity of phospholipase was related to the isolates $V$. alginolyticus, $V$. mimicus, $V$. cholerae and $V$. furnissii; whereas gelatinase was related to the isolates $V$. mimicus, $V$. cholerae and $V$. furnissii, being considered then, species-specific. Among the total of isolates, only two strains (one of $V$. alginolyticus, the other of $V$. furnissi) have not produced this enzyme (Table II).

Lafisca et al. (2008) analyzed strains of Vibrio isolated from bivalve molluscs collected in Italy (Venetian lagoon) and Brazil (Guanabara Bay) in relation to the incidence of elastase, colagenase and condroitinase. They have found in the Brazilian samples a high amount of strains producing elastase $(n=23)$, collagenase $(n=22)$ and chondroitinase $(n=21)$. The authors emphasize that these enzymes are considered the main factors of virulence of $V$. alginolyticus bacteria, especially in cases of human dermatological infections. Lafisca et al. (2008) proved, through molecular techniques, that this vibrio can acquire the genes of virulence from other marine bacteria, serving as a pathogenic reservoir.

Considering the 61 strains analyzed, $n=24$ (39\%) were $\beta$-haemolytic; from these, $\mathrm{n}=9(14 \%)$ were $V$. alginolyticus, followed by $\mathrm{n}=7(11 \%)$ of $V$. cholerae, $\mathrm{n}=6(9 \%)$ of $V$. mimicus and only $\mathrm{n}=1$ (1\%) of $V$. vulnificus and $V$. furnissii. According to Jayaprakash et al. (2006) haemolysis may be considered a virulent determinant, and the chitinolytic, proteolytics and lipolytic might serve as supplementary factors that help the organism invade the host. On the other side, Austin et al. (2005) affirm that the environment of aquaculture serves as an ideal reservoir for virulent lineages of vibrios, being rich in nutrients and antibiotics, it composes the ideal conditions for these microorganisms to develop. Besides, Masini et al. (2007) note that the 
cytotoxicity and the enzymatic activities are not seen only in isolates of clinically relevant species as $V$. alginolyticus, $V$. parahaemolyticus, $V$. vulnificus and $V$. harveyi, but also in strains considered non-pathogenic to humans as $V$. mediterranei, $V$. splendidus, V. campbelli and $V$. salmonicida.

It is possible to suggest that temperature and salinity were the environmental parameters which influenced the isolation of the studied strains the most. Although the high resistance to penicillin $(83.2 \%)$ and ampicillin (50.7\%) from the isolated Vibrio strains, it is not a matter of concern, since this kind of resistance is considered to be intrinsic to this genus.

Finally, the most important results of the research was the high degree of positive strains to virulence factors, as some are related to human diseases and also pathogens of aquatic organisms.

\section{REFERENCES}

\section{ALAGAPPAN K, KARUPPIAH V AND DEIVASIGAMANI}

B. 2016. Protective effect of phages on experimental V. parahaemolyticus infection and immune response in shrimp (Fabricius, 1798). Aquac 453: 86-92.

AKINBOWALE OL, PENG H AND BARTON MD. 2006. Antimicrobial resistance in bacteria isolated from aquaculture sources in Australia. J Appl Microbiol 100: 1103-1113.

ARAÚJO MRE, AQUINO C, SEARAMAL E, CIOLA CS, SCHETTINO G AND MACHADO MCC. 2007. Vibrio vulnificus infection in São Paulo, Brazil: case report and literature review. Braz J Infect Dis 11(2): 302-305.

ARAÚJO DB, MARTINS SCS, ALBUQUERQUE LMB AND HOFER E. 1996. Influence of the copepod Mesocyclops longisetus (Crustácea: Cyclopidae) on the survival of Vibrio cholerae $\mathrm{O} 1$ in fresh water. Cad Saúde Públ 12(4): 551-554.

ARBOLEDA M AND REICHARDT W. 2009. Epizoic communities of prokaryotes on healthy and diseased scleractinian corals in Lingayen Gulf, Philippines. Microb Ecol 57: 117-128.

AUSTIN B. 2010. Vibrios as causal agents of zoonoses. Vet Microbiol 140: 310-317.

AUSTIN B, AUSTIN D, SUTHERLAND R, THOMPSON F AND SWINGS J. 2005. Pathogenicity of vibrios to rainbow trout (Oncorhynchus mykiss, Walbaum) and Artemia nauplii. Environ Microbiol 7(9): 1488-1495.
BATABYAL P, EINSPORN MH, MOOKERJEE S, PALIT A, NEOGI SB, NAIR GB AND LARA RJ. 2014. Influence of hydrologic and anthropogenic actors on the abundance variability of enteropathogens in the Ganges estuary, a cholera endemic region. Sci Total Environ 472: 154-161.

BAUER AW, KIRBY MM, SHERRIN JD AND TURCH M. 1996. Atibiotcs susceptibility testing by standardized single disk method. Am J Clin 45: 493-496.

BENEDUCE L, VERNILE A, SPANO G, MASSA S, LAMACCHIA F AND OLIVER JD. 2010. Occurrence of Vibrio vulnificus in mussel farms from the Varano lagoon environment. Lett Appl Microbiol 51: 443-449.

CANNICCI S, BARTOLINI F, DAHDOUH-GUEBAS F, FRATINI S, LITULO C, MACIA A, MRABU EJ, PENHA-LOPES G AND PAULA J. 2009. Effects of urban wastewater on crab and mollusc assemblages in equatorial and subtropical mangroves of East Africa. Estuar Coast Shelf Sci 84: 305-317.

CLSI - CLINICAL AND LABORATORY STANDARDS INSTITUTE. 2013. Performance standards for antimicrobial susceptibility testing. Twentieth Informational Supplement, M100-S20.

COSTA MM, PEIXOTO RM, BOIJINK CL, CATAGNA L, MEURER F AND VARGAS AC. 2008c. Sensibilidade antimicrobiana de bactérias isoladas de Jundiá (Rhamdia quelen). Pesq Vet Bras 28 (10): 477-480.

COSTA RA, SILVA GC, PEIXOTO JRO, VIEIRA GHF AND VIEIRA RHSF. 2010. Quantification and distribuition of Vibrio species in water from na estuary in Ceará-Brazil impacted by shrimp farming. Braz J Oceanogr 58(3): 183188.

COSTA RA, VIEIRA GHF, SILVA GC, PEIXOTO JRO, VIEIRA RHSF AND SAKER-SAMPAIO S. 2008b. Vibrio microfauna associated with different development stages of the marine shrimp Litopenaeus vannamei. Indian J Comp Microbiol Immunol Infect Dis 29(1-2): 49-51.

COSTA RA, VIEIRA GHF, SILVA GC, VIEIRA RHSF AND SAKER-SAMPAIO S. 2008a. Susceptibilidade "in vitro" a antimicrobianos de estirpes de Vibrio spp. isoladas de camarões (Litopenaeus vannamei) e de água de criação destes animais provenientes de uma fazenda de camarões no Ceará - Nota prévia. Braz J Vet Res Anim Sci 45(6): 458-462.

DANG H, REN J, SONG L, SUN S AND AN L. 2008. Dominant chloramphenicol-resistant bactéria and resistance genes in coastal marine Waters of Jiaozhou Bay, China. World J Microbiol Biotechnol 24: 209-217.

DEVI R, SURENDRAN PK AND CHAKRABORTY K. 2009. Antibiotic resistnace and plasmid profiling of Vibrio parahaemolyticus isolated from shrimp farms along the southwest coast of India. World J Microbiol Biotechnol 25: 2005-2012. 
DUAN J AND SU YG. 2005. Occurrence of Vibrio parahaemolyticus in Two Oregon-growing Bays. J Food Sci 70(1): 58-63.

EILER A, JOHANSSON M AND BERTILSSON S. 2006. Environmetal influences on Vibrio populations in northern termperate and Boreal Coastal Waters (Baltic and Skagerrak Seas). Appl Environ Microbiol 72(9): 60046011.

FIELD C. 1995. Journeys amongst mangroves. International Society for Mangrove Ecosystems, Okinawa, Japan. South China Printing Co., Hong Kong, 140 p.

GROHMANN E, MUTH G AND ESPINOSA M. 2003. Conjugative plasmid transfer in gram-positive bacteria. Microbiol Mol Biol Rev 67(2): 277-301.

HAN F, WALKER RD, JANES ME, PRINYAWIWATKUL W AND GE B. 2007. Antimicrobial susceptibilities of Vibrio parahaemolyticus and Vibrio vulnificus isolates from Louisiana Glf and retail raw oysters. Appl Environ Microbiol 73(21): 7096-7098.

HARRIAGUE AC, DI BRINO M, ZAMPINI M, ALBERTELli G, PRUZZO C AND MISIC C. 2008. Vibrios in association with sedimentary crustaceans in three beaches of the northern Adriatic Sea (Italy). Mar Pollut Bull 56: 574-579.

HOFER E, QUINTAES BR, REIS EMF, RODRIGUES DP, SEKI LM, FEITOSA IS, RIBEIRO LHFF AND FERREIRA MR. 1999. Emergência da múltipla resistência a antimicrobianos em Vibrio cholerae isolados de pacientes com gastroenterite no Ceará, Brasil. Rev Soc Bras Med Trop 32(2): 151-156.

HOFER E, REIS EMF, QUINTAES BR, RODRIGUES DP, FEITOSA IS, ANGELO MRF AND RIBEIRO LHFF. 2001. Vibrio cholerae resistant to 2,4-diamino-6, 7-diisopropylpteridine $(\mathrm{O} / 129)$ isolated from patients with enteritis in Ceará, Brazil. J Helath Popul Nutr 19(1): 39-42.

JAYAPRAKASH NS, KUMAR VJR, PHILIP R AND SINGH ISB. 2006. Vibrios associated with Macrobrachium rosenbergii (De Man, 1879) larvae from three hatcheries on the Indian southwest coast. Aquac Res 37: 351-358.

JAYASREE L, JANAKIRAM P AND MADHAVI R. 2006. Characterization of Vibrio spp. associated with diseased shrimp from culture ponds of Andhra Pradesh (India). J World Aquac Soc 37(4): 523-532.

KAYSNER CAAND DEPAOLAA. 2014. Vibrio. In: Food and Drug Administration - FDA, Bacteriological Analytical Manual on line. Chapter 9. May 2004. Available from: < http://www.cfsan.fda.gov/ ebam/bam-9.html >. Accessed on Oct. 27, 2014.

KEMPER N. 2008. Veterinary antibiotics in the aquatic and terrestrial environment. Ecologic. Indicators 8: 1-13.

KIM Y, CHOI K, JUNG J, PARK S, KIM PG AND PARK J. 2007. Aquatic toxicity of acetaminophen, carbamazepine, imetidine, diltiazem andsix major sulfonamides, and their potential ecological risks in Korea. Environ Int 33: 370375.

KRISHNA BVS, PATIL AB AND CHANDRASEKHAR MR. 2006. Fluoroquinolone-resistant Vibrio cholerae isolated during a cholera outbreak in India. Transact Royal Societ Tropic Medic Hygien 100: 224-226.

KUMAR PA, PATTERSON J AND KARPAGAM P. 2009. Multiple antibiotic resistence profiles of Vibrio cholerae non-O1 and non-O139. Jpn J Infect Dis 62: 230-232.

LAFISCAA, PEREIRA CS, GIACONE V AND RODRIGUES DP. 2008. Enzymatic characterization of Vibrio alginolyticus strains isolated from bivalves harvested at Venice Lagoon (Italy) and Guanabara Bay (Brazil). Rev Inst Med Trop S P 50(4): 199-202.

LEAL NC, SILVA SC, CAVALCANTI VO, FIGUEIROA ACTA, NUNES VVF, MIRALLES IS AND HOFER E. 2008. Vibrio parahaemolyticus serovar O3:K6 gastroenteritis in northeast Brazil. J Appl Microbiol 105: 691-697.

LIU PC, LEE KK AND CHEN SN. 1996. Pathogenicity of different isolates of Vibrio harveyi in Tiger prawn, Penaeus monodon. Lett Appl Microbiol 22: 413-416.

MAGALHÃES TF, VIEIRA RHSF, FAÇANHA SHF, HOFER E AND MARTIN AM. 2000. Note. Growth of Vibrio parahaemolyticus in lobster homogenates at different temperatures. Food Sci Tech Int 6(2): 145-150.

MAGALHÃES V, CASTELLO FILHO A, MAGALHÃES M AND GOMES TT. 1993. Laboratory evaluation on pathogenic potentialities of Vibrio furnissii. Mem Inst Oswaldo Cruz 88(4): 593-597.

MAHMUD ZH, NEOGI SB, KASSU A, WADA T, ISLAM MS, NAIR GB AND OTA F. 2007. Seaweeds as a reservoir for diverse Vibrio parahaemolyticus populations in Japan. Int J Food Microbiol 118: 92-96.

MAPA - MINISTÉRIO DA AGRICULTURA, PECUÁRIA E ABASTECIMENTO. 2003. Proibe a fabricação, a manipulação, o fracionamento, a comercialização, a importação e o uso dos princípios ativos cloranfenicol e nitrofuranos e os produtos que contenham estes princípios ativos, para uso veterinário e suscetível de emprego na alimentação de todos os animais e insetos. Instrução Normativa, Brasília, número 9 de 27 de junho.

MARINS RV, PAULA FILHO FJ AND ROCHA CAS. 2007. Geoquímica de fósforo como indicadora da qualidade ambiental e dos processos estuarinos do Rio Jaguaribe costa nordeste oriental brasileira. Quím Nova 30(5): 12081214.

MASINI L, DE GRANDIS G, PRINCIPI F, MENGARELLI C AND OTTAVIANI D. 2007. Research and characterization of pathogenic vibrios from bathing water along the Conero Riviera (Central Italy). Water Resv 41: 4031-4040.

MENDES ES, ALVES CAB, BEZERRA SS, MENDES PP AND SANTOS FL. 2004. Sensibilidade in vitro à 
enrofloxacina e oxitetraciclina de Vibrio isolados na larvicultura de camarão marinho (Litopenaeus vannamei). Ciênc Vet Trop 7(2 -3): 90-97.

MENDES ES, MENDES PP, GÓES LMNB, BEZERRA SS AND VIEIRA KPBA. 2005. Os víbrios na carcinicultura. Panor Aquic, p. 26-29.

MIZUNO T, SULTAN SZ, KANEKO Y, YOSHIMURA T, MAEHARA Y, NAKAO H, TSUCHIYA T, SHINODA S AND MIYOSHI SI. 2009. Modulation of Vibrio mimicus hemolysin through limited proteolysis by an endogenous metalloprotease. FEBS J 276: 825-834.

MOLINA-AJA A, GARCIA-GASCA A, ABREU-GROBOIS A, MEJÍA-BOLÁN C, ROQUE A AND GOMEZ-GIL B. 2002. Plasmid profiling and antibiotic resistance of Vibrio strains isolated from cultured penaeid shrimp. FEMS Microbiol Lett 213: 7-12.

MONTES M, FARTO R, PÉREZ MJ, ARMADA SP AND NIETO TP. 2006. Genotypic diversity of Vibrio isolates associated with turbot (Scophthalmus maximus) culture. Res Microbiol 157: 487-495.

MUDRYK ZJ. 2005. Occurrence and distribution antibiotic resistance of heterotrophic bacteria isolated from a marine beach. Mar Pollut Bull 50: 80-86.

NOGUEROLA I AND BLANCH AR. 2008. Identification of Vibrio spp. with a set of dichotomous keys. J Appl Microbiol 105: 175-185.

NORIEGA-OROZCO L, ACEDO-FÉLIX E, HIGUERACIAPARA I, JIMÉNEZ-FLORES R AND CANO T. 2007. Pathogenic and non pathogenic Vibrio species in aquaculture shrimp ponds. Rev Latinoam Microbiol 49(34): 60-67.

OKUDA J, KANAMURU S, YUASA A, NAKAOKA N, KAWAKAMI H AND NAKAI T. 2006. A possible mechanism of quinolona resistene in Vibrio anguillarum. Fish Pathol 41(2): 73-75.

PRENSA LATINA - AGÊNCIA INFORMATIVA LATINOAMERICANA. 2011. Haiti registra 4.030 mortos por cólera. Available from: http://www.prensa-latina. $\mathrm{cu} /$ index.php?option $=$ com_content $\& \operatorname{task}=\mathrm{v}$ iew\&id $=$ 259199\&Itemid=1. Accessed on Fev. 02, 2011.

RAHAMN S, KHAN SN, NASER MN AND KARIM MM. 2010. Isolation of Vibrio spp. From penaeid shrimp hatcheries and coastal waters of Cox's Bazar, Bangladesh. Asian J Exp Biol Sci 1(2): 288-293.

RANDRIANARIVELO R, DANTHU P, BENOIT C, RUEZ P, RAHERIMANDIMBY M AND SARTER S. 2010. Novel alternative to antibiotics in shrimp hatchery: effects of the essential oil of Cinnamosma fragrans on survival and bacterial concentration of Penaeus monodon larvae. J Appl Microbiol 109: 642-650.

REBOUÇAS RH, SOUSA OV, LIMA AS, VASCONCELOS FR, CARVALHO PB AND VIEIRA RHSF. 2011. Antimicrobial resistance profile of Vibrio species isolated from marine shrimp farming environments (Litopenaeus vannamei) at Ceará, Brazil. Environ Res 111(1): 21-24.

RODRIGUES SMA, GONÇALVES EGR, MELLO DM, OLIVEIRA EG AND HOFER E. 2001. Pesquisa de bactérias do gênero Vibrio em feridas cutâneas de pescadores do município de raposa-MA. Rev Soc Bras Med Trop RJ 34(5): 407-411.

SMITH P. 2007. Antimicrobial use in shrimp farming in Ecuador and emerging multi-resistance during the cholera epidemic of 1991: A re-examination of the data. Aquac 271: $1-7$.

SOUSA OV. 2004. Vibrio parahaemolyticus. In: Vieira RHSF (Ed), Microbiologia, Higiene e Qualidade do Pescado teoria e prática. p. 219-226.

SOUSA OV, MACRAE A, MENEZES FGR, GOMES NCM, VIEIRA RHSF AND MENDONÇA-HAGLER LCS. 2006. The impacto of shrimp farming effluent on bacterial communities in mangrove Waters, Ceará, Brazil. Mar Pollut Bull 52: 1725-1734.

SRINIVASAN P AND RAMASAMY P. 2009. Occurrence, distribution and antibiotic resistance patterns of Vibrio species associated with viral disease Shrimp of South Indian Aquaculture Environment. Int J Agric Sci 1(2): 0110.

SUGITA H AND ITO Y. 2006. Identification of intestinal bacteria from Japanese flounder (Paralichthys olivaceus) and their ability to digest chitin. Lett Appl Microbiol 43: 336-342.

SUNG HH, HSU SF, CHEN CK, TING YY AND CHAO WL. 2001. Relationships between disease outbreak in cultured tiger shrimp (Penaus monodon) and the composition of Vibrio communities in pond water and shrimp hepatopancreas during cultivation. Aquacul 192: 101-110.

TAKAHASHI A, MIYOSHI SI, TAKATA N, NAKANO M, HAMAMOTO A, MAWATARI K, HARADA N, SHINODA S AND NAKAYA Y. 2007. Haemolysin produced by Vibrio mimicus activates two $\mathrm{Cl}-$ secretory pathways in cultured intestinal-like Caco-2 cells. Cell Microbiol 9(3): 583-595.

THOMPSON CC, THOMPSON FL AND VICENTE ACP. 2008. Identification of Vibrio cholerae and Vibrio mimicus by multilocus sequence analysis (MLSA). Int J Syst Evol Microbiol 58: 617-621.

THOMPSON FL, IIDA T AND SWINGS J. 2004. Biodiversity of Vibrios. Microbiol Mol Biol Rev 69 (3): 403-431.

VIEIRA RHSF, LIMA AS, MENEZES FGR, COSTA RA, SOUSA OV AND EVANGELISTA-BARRETO NS. 2009. Vibrioses em camarão cultivado. Arq Cienc Mar 42: 112120.

YATES CM, PEARCE MC, WOLHOUSE MEJ AND AMYES SGB. 2004. High frequency transfer and horizontal spread of apramycin resistance in calf faecal Escherichia coli. J Antim Chem 54: 534-537. 